\title{
Sustainable use of water resources in a Wadi system facing climate change impacts and growing groundwater demand
}

\author{
Nariman Mahmoodi ${ }^{1}$, Jens Kiesel ${ }^{1,2}$, Paul D. Wagner ${ }^{1}$, Nicola Fohrer ${ }^{1}$ \\ ${ }^{1}$ Kiel University, Department of Hydrology and Water Resources Management, Kiel 24118, Germany
}

$5{ }^{2}$ Leibniz-Institute of Freshwater Ecology and Inland Fisheries, Department of Ecosystem Research, Berlin 12489, Germany

Correspondence to: Nariman Mahmoodi (nmahmoodi@hydrology.uni-kiel.de)

\begin{abstract}
Understanding current and possible future alterations of water resources under climate change and increased water withdrawal allows for better water and environmental management decisions in arid regions. This study aims at analyzing the impact of groundwater withdrawals and climate change on groundwater sustainability and hydrologic regime alterations

10 in a Wadi system in central Iran. A hydrologic model is used to assess streamflow and groundwater recharge of the Halilrood Basin on a daily time step under different scenarios over a model setup period (1979-2009) and for two future scenario periods (near future: 2030-2059 and far future: 2070-2099). The Indicators of Hydrologic Alteration (IHA) with a set of 32 parameters are used in conjunction with the Range of Variability Approach (RVA) to evaluate hydrologic regime change in the river. The results show that groundwater recharge is expected to decrease, and is not able to fulfil the increasing water

15 demand in the far future scenario. The Halilrood River will undergo low and moderate flow alteration under both stressors during the near future as RVA alteration is classified as "high" for only three indicators, while in the far future, 11 indicators lie in "high" range. Absolute changes in hydrologic indicators are stronger when both climate change and withdrawals are considered in the far future simulations, since 27 indicators show significant changes and RVA show high and moderate level of changes for 18 indicators. Considering the evaluated RVA changes, future impacts on the freshwater ecosystems in

20 the Halilrood Basin will be severe. The developed approach can be transferred to other Wadi regions for a spatiallydistributed assessment of water resources sustainability.
\end{abstract}

\section{Introduction}

Water resources are important in arid regions and any alteration caused by natural or anthropogenic activities might have strong environmental and socio-economic impacts. This poses a serious threat to the sustainable development of water resources in different sectors (Oki and Kanae, 2006 and Panahi et al., 2020). Hence, sustainable management of water resources is vital especially in arid regions with limited water availability (Wu et al., 2013; Davijani et al., 2016; Yu et al., 2019).

Sustainable use of water resources should be jointly assessed with regard to surface water and groundwater. Groundwater is not only a valuable source of high-quality freshwater and plays a central role in sustaining water supplies and rural 
30 livelihoods in arid regions (Giordano, 2009; Cuthbert et al., 2019), but also contributes to baseflow and the functioning of freshwater ecosystems (Boulton and Hancock, 2006; Kath et al., 2018). Excessive groundwater withdrawal for a wide variety of activities, is causing aquifers to rapidly deplete worldwide (Gleeson and Wada, 2013). Groundwater withdrawal has more severe consequences in arid and semi-arid regions, where surface water is insufficient to meet human water demand especially in times of droughts and natural groundwater recharge is low (Long et al., 2016; Taylor, 2014).

35 Moreover, the existence of different and effective groundwater withdrawal systems such as qanats and wells in arid regions can lead to pronounced groundwater depletion (Eissa et al., 2016; Perrone and Jasechko, 2019). Substantial and persistent drops in groundwater levels are expected when the ratio of groundwater withdrawal exceed recharge from infiltration and river transmission losses over the basin (de Graff et al., 2019; Acero Triana et al., 2020). Therefore, the ratio of groundwater withdrawal to the recharge rate is a potential indicator of regional water security (Richey et al., 2015) and sustainability.

40 Little and sporadic precipitation, very high evaporation, little percolation and groundwater recharge are the peculiar features of Wadi regions (Pahlevani Majdabady et al., 2020; Messerschmid et al., 2020). In Iran, the scarcity of rainfall, combined with climate change and population growth over the last decades, has resulted in higher groundwater extraction rates (Izady et al., 2015; Rafiei Emam et al., 2015; Mahmoudpour et al., 2016). Therefore, estimating the current and future amount of average annual groundwater recharge and storage under climate change conditions and by incorporating growing water

45 demands due to development and population growth is critical and fundamental for a sustainable management of groundwater and surface water (Dash et al., 2019).

Moreover, hydrological changes caused by climate change and population growth are not limited to groundwater, but also extend to surface water resources, where changes in runoff timing, seasonality, peak rates and volumes of surface water have been reported for different arid parts of Iran (Ashraf et al., 2019) and other countries e.g., United States of America

50 (Caldwell et al., 2012), Algeria (Achite and Ouillon 2016), China (Xue et al., 2017), and Jordan (Al Qatarneh et al., 2018). Alteration of the flow regime could have negative environmental consequences, as e.g., in China, decreases in water resources had a negative effect on the semi-arid wetland ecosystem of Western Jilin (Moiwo et al., 2010). Wen et al., (2013) reported that reduction in streamflow is the principal cause of the decrease in ecological values of a semi-arid wetland in Australia. Similarly in the northwest of Iran, a dramatic reduction of the water level of Urmia lake has been reported by 55 Khazaei et al., (2019) due to the reduced inflow to the lake from the entire basin. Moreover, the Bakhtegan and Tashk lakes in southern Iran started to disappear due to hydrologic regime changes in Kore River, which altered the inflow to the lakes (Haghighi and Kløve 2017). The fluctuation of streamflow in Hirmand basin caused several hydrologic and environmental effects such as a decrease in water level of Hamoun wetland, increasing wildlife death rates, and increasing air pollution and consequently health problems, in southwestern Iran (Sharifikia, 2012). In addition, Nielson and Brock (2009) found a shift in

60 species distribution in wetlands of Southern Australia due to flow regime alteration and salinity induced by climatic changes. According to Qaderi Nasab and Rahnema (2020), the Jamorian wetland, which is fed by Wadis in central Iran, has undergone significant changes in area and seasonal availability of water between 1987 and 2017. In addition, they reported very low soil moisture in the wetland area due to decreasing inflows and high potential evapotranspiration (more than 2800 
mm yr-1), which increases vulnerability of the wetland to wind erosion. Modarres and Sadeghi (2018) showed that the dust from the wetland increased the number of dusty days in Iranshahr city, which is almost $180 \mathrm{~km}$ away from the wetland. Vulnerability of wetlands to wind erosion has also been found in other arid regions e.g., the dried-up Ebinur Lake region in northwestern China has become one of the main dust sources as a consequence of the change of inflow to the lake (Bao et al., 2006). Further aggravation will put increasing pressure on the already threatened natural ecosystem of Wadi regions. Therefore, future susceptibility of Wadis to climate change and groundwater withdrawals is important to understand.

70 Recognizing the above concerns, this study aims to: (1) assess the sustainability of groundwater in the future by modeling the recharge rate under climate change and predicted withdrawals, (2) explore the possible future hydrologic alterations of rivers in Wadi regions and to evaluate their ecological implications.

\section{Materials and methods}

\subsection{Study area}

75 The Halilrood Basin $\left(7224 \mathrm{~km}^{2}\right)$ is located in central Iran (Figure 1a). It is a major river in the Kerman province in terms of discharge, and provides various ecosystem services, as the water is used for domestic, industrial, energy (Jiroft Dam, Figure 1b), and agricultural (small scale farming) purposes, and it provides water to the Jazmorian wetland (Figure 1b), mainly from February to April (Figure 1c). Annual average precipitation in Halilrood Basin varies between $121 \mathrm{~mm}$ to $511 \mathrm{~mm}$ with an average of $295 \mathrm{~mm}$ (1979-2011). The annual potential evaporation is more than $2500 \mathrm{~mm}$ and the mean annual discharge

$80\left(7.68 \mathrm{~m}^{3} \mathrm{~s}^{-1}\right)$ is about one tenth of the precipitation. More seriously, flow intermittency has increased over the last years at the outlet of the basin during the past 33 years (1979-2011), mostly in 2005 and 2007. Regarding land cover, bare land areas occupy about $75 \%$ of the basin. According to Mahmoodi et al., (2020a), shrubland and grassland areas can be found in the highlands, whereas irrigated agriculture is existing only in proximity to the rivers and water use systems (WUSs: qanats, wells, springs). Three cities, i.e. Baft, Bazanjan, Rabor are located in the northern part of the basin (Figure 1d). The extracted

85 water from shallow aquifer through springs, qanats, and wells drilled in different parts of the basin (Figure 1e), is used to supply water to the cities and villages mainly for drinking and washing and to small-scale farming for irrigation.

\subsection{Hydrological model}

The Soil and Water Assessment Tool (SWAT, Arnold et al., 1998; Arnold et al., 2012) was used to simulate the streamflow of Halilrood River between 1993 and 2009 on a daily time step. SWAT is a semi-distributed model which is most commonly

90 applied to simulate water fluxes on the catchment scale with diverse agricultural management options and under various hydrologic conditions over long periods of time (Arnold et al., 2012). The SWAT model of the Halilrood Basin is divided into 285 sub-basins and 6091 hydrologic response units (HRUs) defined by land use, slope, and soil type. Based on representative climatic conditions, an eight-year period was used for model calibration (1995-2003) and a six-year period for validation (2004-2009). Water use systems (WUSs) and soil and water conservation measures (SWCMs) scattered within 
the basin were implemented in the model (Mahmoodi et al., 2020a). Good performance for modeling daily streamflow values was achieved judged by a multi-metric approach including NSE (0.76 and 0.54), PBIAS (4.7 and 7.1), RSR (0.49 and 0.78), and the modified $\mathrm{KGE}(0.87$ and 0.62) for calibration and validation period, respectively. More detailed setup description and evaluation of model performance are available in Mahmoodi et al., (2020a).

\subsection{Future climate change simulation}

Mahmoodi et al., (2020b) used an ensemble of global and regional climate models (G-RCMs) from the Coordinated Regional Climate Downscaling Experiment-CORDEX (Jacob et al., 2014) to assess the impact of future climate change on streamflow and major hydrological components of the Halilrood Basin. Climate data of the two Representative Concentration Pathways (RCP) 4.5 and 8.5 were bias corrected with two methods (distribution mapping and linear scaling) and evaluated alongside the raw (not bias corrected) data. For the present impact study, following the argumentation that errors level out and a projection can be better represented through averaging, i.e., taking the mean, median, or weighting (Tebaldi and Knutti 2007, Thober and Samaniego, 2014), from the RCP8.5 and distribution mapping-adjusted ensemble, one global-regional climate model was selected. This selection was conducted according to the model democracy approach, which treats all climate models equally and the median model of the model ensemble is selected (IPCC, 2013). The G-RCM CSIRO-SMHI was chosen since it represented the median model of the major hydrological components (Mahmoodi et al.,

110 2020b). The calibrated and validated SWAT model was run with this climate model output to simulate groundwater recharge and streamflow for the model setup period (1979-2009) and two future periods (near future: 2030-2059 and far future: 20702099).

\subsection{Future population growth and water demand}

Based on the data reported by the Statistics Cerner of Iran (SCI, 2017), Iran has experienced a remarkable population

115 increase within the last few decades (from 33.7 mil. in 1976 to more than 80 mil. in 2017 (Dienel et al., 2017)). According to the last census in 2017, the total urban and rural population of Halilrood Basin was 124,000 (Statistical Center of Iran-SCI, 2017). The population growth rate suggested by presidency of I.R.I, Plan and Budget Organization (2019) was applied on the 2017 population data to estimate the population of the basin for the years 2045 and 2085, representative for the near and far future periods respectively (Table 1).

Future water demand in Halilrood Basin is projected by considering (i) groundwater withdrawal from WUSs and (ii) minimum and maximum water consumption for the estimated population.

(i): To meet the future domestic, agricultural and industrial water demand, increases in the number of wells and qanats are linearly extrapolated with the estimated increases in the population of Halilrood Basin as follows: 
Where NWUSj and NWUSi are the number of water use systems in the year $\mathrm{j}$ and $\mathrm{i}$, respectively; $\mathrm{Pj}$ and $\mathrm{Pi}$ is population in the year $\mathrm{j}$ and $\mathrm{i}$, respectively. The number of springs as a natural WUS is assumed to remain constant in the future. The annual average water withdrawal per WUS recorded for the model setup period is assumed to remain constant in the future and is used to linearly extrapolate the required groundwater withdrawal for each sub-basin for the future number of WUS

130 (NWUSj) for 2045 and 2085 (Table 2).

(ii): The minimum and maximum amount of water required per person per day in Iran is about 0.135 and $0.300 \mathrm{~m}^{3}$, respectively (ISC, 2017-2018). According to these numbers and the estimated population growth (Table 1), maximum and minimum water consumption in near and far future are estimated (Table 3).

\subsection{Scenarios}

135 To disentangle the impacts of climate change and population growth and its combined effects on future aquifer condition and hydrologic regime, five scenarios were developed (Table 4). "NO-WUS" scenario is included, to assess the sole impact of climate change on the hydrologic regime under pristine conditions. It therefore represents a scenario where all anthropogenic extractions have ceased. "Constant-WUS" scenario is defined to investigate the impact of climate change on hydrologic regime and groundwater sustainability in the future simulations in comparison to the current condition by keeping the

140 number of WUSs unaltered. The impacts of both climate change and WUSs on groundwater sustainability and hydrologic regime are assessed under "Projected-WUS" scenario. To precisely indicate the impact of the sole water demand by the population on groundwater sustainability in near and far future, the maximum and minimum amount of water required per person is computed and considered under "Min- and Max-Consumption" scenarios. These two scenarios are considered only on entire basin scale due to limited availability of information regarding population growth on smaller scales (e.g., villages).

145 Minimum and maximum water consumption is included in the Constant- and Projected-WUS scenarios.

\subsection{Groundwater sustainability}

Groundwater sustainability is assessed on two different spatial scales: on the sub-basin and on the entire basin scale.

\subsubsection{Sub-basin scale}

Groundwater sustainability (GWS) on the sub-basin scale is defined as the ratio of groundwater withdrawal (GWW) to 150 groundwater recharge (GWR).

To provide an appropriate estimate and range of the future aquifer condition on the sub-basin scale, groundwater withdrawal for the model setup period and two future periods is estimated for two scenarios: Projected-WUS and Constant-WUS.

\subsubsection{Entire basin scale}

On the entire basin scale (entire Halilrood Basin), groundwater sustainability (GWS) is assessed by comparing the total 155 groundwater recharge (GWR) over the entire basin to (i) the total projected groundwater withdrawal (GWW) from the 
WUSs under Projected-WUS scenario, (ii) the minimum, and (iii) the maximum water consumptions (Min- and Max-WC) estimated for the growing population under Max- and Min-Consumption scenarios.

\subsection{Indicators of Hydrologic Alteration (IHA)}

Changes in the hydrologic regime of the Halilrood River that are caused by climate change and groundwater withdrawal are not only a challenge for the water sector (e.g., small-scale farming), but also decrease groundwater levels and threaten the Jazmorian wetland ecosystem by reducing its water availability. The hydrologic alteration is analyzed under following scenarios: No-WUS, Constant-WUS, and Projected-WUS.

Numerous hydrologic indicators have been developed to describe different components of the flow regime. A set of 32 hydrologic indicators were used to assess changes in the hydrologic flow regime (Richter et al., 1996). The indicators are categorized into five groups; Group1: Magnitude of monthly water conditions, Group2: Magnitude of annual extreme discharge events with different durations, Group3: Timing of annual extreme water conditions, Group4: Frequency and duration of high and low pulses, and Group5: Rate and frequency of water condition changes (Table 5). The "IHA" software developed by The Nature Conservancy (TNC, 2009) was used to attribute the characteristic of intra- and inter-annual variations in streamflow based on simulated daily discharge for baseline (1982-2011) and future periods (2030-2059 and

170 2070-2099) under the three different WUS scenarios (No-, Constant-, and Projected-WUS). An ANOVA test was applied with a significance level of $5 \%$ to evaluate the significant differences of IHA in near and far future of each of the aforementioned scenarios compared to the baseline as suggested in Vu et al., (2019).

The Range of Variability Approach (RVA) established by Richter et al., (1997) was applied to evaluate flow regime alteration caused by climate change and groundwater withdrawals (WUSs). The RVA category thresholds were set as the median \pm 25 th percentile of the baseline data for each hydrologic indicator using non-parametric statistics. The degree of alteration (DA) is calculated as (The Nature Conservancy, 2009):

$$
D A i=\frac{R o i-R e i}{R e i} * 100 \% \text {, }
$$

Where DAi is the degree of hydrologic alteration of the ith IHA; Roi and Rei are the number of observed and expected repetitions in the scenario period for the ith IHA falling within the RVA target range. Rei is defined as:

$$
R e i=\gamma R t
$$

Where $\gamma$ is the proportion of a single indicator's values falling within the RVA target range in the near and far future, i.e. $\gamma=$ 0.5 is the suggested RVA target range between the 25 th and 75 th percentile values. Rt is the total number of values for each indicator in the near and far future (30 years period), i.e. Rt = 30 (Richter et al., 1997; Zhang et al., 2019).

To evaluate the magnitude of change for each indicator, Richter et al., (1998) divided DAi (absolute value) into three classes: $1850- \pm 33 \%$ represents no or low alteration $(\mathrm{L}), \pm 33 \%- \pm 67 \%$ represents moderate alteration $(\mathrm{M})$, and $\pm 67 \%- \pm 100 \%$ represents 
https://doi.org/10.5194/hess-2020-599

Preprint. Discussion started: 13 January 2021

(c) Author(s) 2021. CC BY 4.0 License.

high alteration $(\mathrm{H})$. The direction of change is shown by positive RVA, where the indicator becomes more stable within the RVA targets and negative RVA, where the indicator is moving towards an upper or lower alternative state.

\section{Results}

\subsection{Groundwater sustainability}

190 Groundwater sustainability assessment is evaluated on the sub-basin and entire basin scale.

\subsubsection{Sub-basin scale}

The SWAT model of the Halilrood Basin is divided into 285 sub-basins, however, WUSs are located only in 73 sub-basins corresponding to almost 33\% (around $2385 \mathrm{~km}^{2}$ ) of the total area of the Halilrood Basin. 31 of all 73 sub-basins with WUSs represent a sustainable state (GWR>GWW) in the model setup period, however, in 42 sub-basins (17\% of the total area) the amount of extracted water from groundwater is higher than GWR. The rate of GWW to GWR is greater than 2 in 22 subbasins and 5 in 8 sub-basins.

The impact of climate change on groundwater recharge is assessed in the future periods for Constant-WUS scenario (Figure $2 b$ and $d)$. In the near future (Figure $2 b$ ), the number of sub-basins with a sustainable state (GWR $>G W W$ ) decreases from 31 (model setup period) to 26, while the unsustainable subbasins (GWW $<\mathrm{GWR}$ ) covering an area of $1211 \mathrm{~km}^{2}$ (model setup 200 period) increases to $1419 \mathrm{~km}^{2}$ (20\% of the total area). In the far future (Figure 2d), $25 \%$ of the entire basin (55 sub-basins) reach an unsustainable state, where GWW/GWR ratio is higher than 2 in 24 sub-basins and among these above 5 in 9 subbasins.

As shown in Figure 2c and e, the GWW/GWR ratio is higher in the near and far future if the two stressors climate change and population growth are considered simultaneously (Projected-WUS). Already 25\% of the entire basin reach an 205 unsustainable state in the near future (Figure 2c), similar to what we estimated to occur in the far future under the ConstantWUS scenario (Figure 2d). In the far future, among 73 sub-basin with WUSs, only 8 sub-basins are sustainable and in 56 sub-basins groundwater use is twice the simulated recharge (Figure 2e). Among these 56 unsustainable sub-basins, GWW/GWR ratio is higher than 5 in 42 sub-basins. 
https://doi.org/10.5194/hess-2020-599

\subsubsection{Entire basin scale}

210 Groundwater recharge is simulated for the model setup, near, and far future periods (Table 6). The groundwater recharge is estimated to decrease in future under climate change. This reduction is more severe in far future, when it drops from 385 $\left(106 \mathrm{~m}^{3} \mathrm{yr}^{-1}\right)$ in model setup period to $172\left(106 \mathrm{~m}^{3} \mathrm{yr}^{-1}\right)$. A sustainable groundwater situation is expected for the entire Halilrood Basin in the near and far future, if we only account for the minimum and maximum water consumption for the growing population (Min- and Max-Consumption/GWR < 1). However, if we consider the increases in number of WUSs in

215 the future (Projected-WUS), groundwater is only sustainable in near future (GWW/GWR=0.59), whereas in far future groundwater recharge is not able to fulfill the increasing demand, where GWW/GWR is 1.35 (Table 6).

\subsection{Hydrologic alteration}

\subsubsection{IHA-Group 1}

The median monthly flows are expected to decrease in the future. This reduction is not significant in the near future for No-

220 WUS, although, a moderate RVA change is shown in late spring, summer, and early autumn. 3 out of 12 and 8 out of 12 indicators are significantly changed respectively in scenarios Constant-WUS and Projected-WUS (Table 8).

In the far future, 11 out of 12 median monthly flows are expected to decrease significantly (Table 8), and the flow changes in Aug, Sep, and Oct are classified as "high" (Figure 3) for all scenarios.

Strongest changes in monthly flows are expected for March under the Projected-WUS scenario where the flow decreased by 22513.2 and $20.2 \mathrm{~m}^{3} \mathrm{~s}^{-1}$ respectively in the near and far future (Table 8). This might be due to the higher reduction in projected winter precipitation (Mahmoodi et al., 2020b).

The magnitude of changes expected under the three WUS scenarios (No-, Constant-, and Projected-WUS) are different. For instance, for the month of March which is subject to the strongest impact, the expected decrease under No-WUS scenario (corresponding to the singular impact of climate change) is $10.1 \mathrm{~m}^{3} \mathrm{~s}^{-1}$ in the near future, whereas under Constant- and 230 Projected-WUS scenarios (corresponding to the impact of climate change and groundwater withdrawals) the expected decreases are $11.6 \mathrm{~m}^{3} \mathrm{~s}^{-1}$ and $13.2 \mathrm{~m}^{3} \mathrm{~s}^{-1}$, respectively. 
https://doi.org/10.5194/hess-2020-599

\subsubsection{IHA-Group 2}

In the near future, minimum flows are expected not to change significantly for No-WUS and Constant-WUS, while 3 out of 5 indicators will decrease pronouncedly for Projected-WUS (Table 8). In the far future scenario, the alteration in minimum

235 flow indicators is classified as "high" (Figure 3) and decrease significantly, as the seasonal moving average declines by 1.1 $\mathrm{m}^{3} \mathrm{~s}^{-1}(87 \%)$ under the three scenarios (No-, Constant-, and Projected-WUS; Table 8). Although annual extreme flows mainly experience a lower degree of change in the near and far future (Figure 3 and 4), the change is more significant in the far future for the Projected-WUS scenario for which seasonal maximum flow decrease $22.4 \mathrm{~m}^{3} \mathrm{~s}^{-1}$ (35\%) compared to the baseline (Table 8). Also, alteration in the magnitude of base flow is estimated to be moderate and high in the near and far 240 future, respectively (Figure 3). However, this alteration is only significant when WUS are considered. The reduction of base flow during the near future under climate change is $0.01 \mathrm{~m}^{3} \mathrm{~s}^{-1}(44 \%)$, which doubles when both climate change and extraction are considered in the future simulation (Table 8).

\subsubsection{IHA-Group 3}

Lowest flows are projected to occur earlier in all three scenarios, around three months for the near future (shift from Sep to

245 June) and more than 4 months for the far future (shift from Sep to April). Also, the date of peak flow will shift around two month and is estimated to happen earlier (shift from March to January) in both the near and far future of all scenarios.

\subsubsection{IHA-Group 4}

The number of low pulses is estimated to increase in the future but this change is not significant in any scenario. The duration of low pulse is expected to increase significantly in the near future for all scenarios, whereas it is not significant in 250 the far future except for the Projected-WUS scenario. The number of high pulses decreases significantly only in the near future. The duration of high pulses does not change significantly in the near and far future in all scenarios. Number of days with no flow will increase significantly in both the near and far future under the three scenarios. This alteration is more severe for the far future under Projected-WUS scenario with 136 days more no-flow days as compared to the baseline (Table 8). 
https://doi.org/10.5194/hess-2020-599

255 The alterations in frequency and duration of high and low pulses under No-WUS in near and far future, are similar to the alterations expected under Constant- and Projected-WUS. For instance, the number of high pulses (Hi Pulse) is estimated to reduce similarly $(-2)$ under all three scenarios.

\subsubsection{IHA-Group 5}

Fall and rise rates as indicators showing variability if streamflow is subject to significant changes only in the far future under

No- and Constant-WUS scenarios, which lies in the lower range of RVA alteration (Figure 3).

The annual values and total distribution of each hydrologic parameters for the baseline and two future periods under different scenarios are shown in supplementary document, Fig. S1 and Fig. S2.

\section{Discussion}

The spatio-temporal variations of ratio of groundwater use to groundwater recharge in the Halilrood Basin is compromising groundwater sustainability in the near and far future. These challenges are expected to be more severe when both climate change and population growth are considered in our scenarios. In addition, groundwater sustainability on the sub-basin scale for the Projected-WUS scenario as compared to Constant-WUS shows that the increases in groundwater withdrawal and consumption exacerbate the negative impact of climate change on groundwater sustainability. To predict future groundwater withdrawal, we used population growth as the main driver. However, increases in number of days with zero flow coincide with higher temperature and evapotranspiration rate, and shifts in the precipitation regimes caused by climate change (Mahmoodi et al., 2020b). While we considered this reduction in water availability, the changing climate may lead to increasing irrigation requirements and may put the existing water use systems under additional pressure as similarly revealed in Toews and Allen (2009).

The rising water demand and WUSs will cause a decline of groundwater levels, due to the imbalance between the groundwater recharge under climate change and estimated groundwater withdrawal in the future. This is not only resulting in an unsustainable groundwater use on sub-basin level and in the entire basin, but also changes the hydrologic regime and ecosystem condition by reducing the contribution of groundwater to streamflow, as 22 and 27 indicators show significant changes respectively for the near and far future under the Projected WUS scenario.

The evaluation of indicators defined for monthly flows in the near future show that groundwater withdrawal strongly affects the hydrologic regime of the Halilrood Basin during the dry season (spring, summer, and autumn) as opposed to the wet season (winter), when the changes of monthly flows are not significant under the Projected-WUS scenario. This is in agreement with the findings of Kakaei et al., (2018) which revealed substantial deficits in discharge during the dry season 
https://doi.org/10.5194/hess-2020-599

Hydrology and

Preprint. Discussion started: 13 January 2021

(c) Author(s) 2021. CC BY 4.0 License.

(summer) of the Eskandari Watershed in central Iran due to human activities (abstraction of groundwater and surface water for irrigation purpose).

285 The predicted unsustainability of groundwater could be even more intense if we focus on the changes projected for the magnitude and timing of annual extreme conditions, in which base, minimum and maximum flows are projected to decrease and a 4 months shift is expected for minimum flows to occur earlier (shift from Sep to June). This could lead to a higher groundwater withdrawal in summer season when the surface water does not meet the rising demand.

In the near and far future, monthly flows and annual extreme flows are expected to decrease. However, the different

magnitude of changes under the three WUS scenarios (No-, Constant-, and Projected-WUS) indicated that the influence of climate change on the flow regime alteration is stronger than groundwater withdrawals. This is in agreement with previous studies e.g., Döll and Zhang (2010) and Shahid et al., (2018). In addition, the similar results for timing, frequency and duration of extreme hydrologic parameters under all three scenarios also showed that their changes are mainly caused by climate change.

295 Since the Halilrood River is the most important source of water in the region, the significant changes in hydrologic alteration indicators may have an impact on the ecosystem of the Wadi and Jazmorian wetland (water presence, area of water body, water depth, and wetland species). We are expecting smaller inundated area and shallower water body in Jazmorian wetland under climate change condition and groundwater withdrawal, as 27 hydrologic regime indicators are representing substantial alterations since out of 32 RVA 12 are classified as "high" and 15 as "moderate". Simultaneously, the availability of water for the wetland is reduced since, among 23 IHA considered for the magnitude of monthly flows and annual extreme flows, 21 IHA have indicated significant changes and 15 IHA show high and moderate levels of alteration based on the RVA approach. Moreover, we expect lower water availability in future for the wetland due to increases in the number and duration of low pulses and number of days with zero flow as well as decreases estimated for the number and duration of high pulses. The significant alteration in falling rates, coinciding with alteration in the magnitude of flows, might influence soil moisture in the wetland and consequently change the distribution of the plants by an intensification of drought stress on plants, preventing wind and water erosion in the Jazmoriam wetland. In summary, hydrologic regime alteration caused by climate change and groundwater withdrawal, will contribute substantially to the ecological change of the wetland and hence, influence the freshwater ecosystem of Wadis in central Iran according to our RVA analysis.

Assessing the streamflow regime changes using IHA in conjunction with RVA, provide a proxy on initial ecological responses to the hydrologic regime changes without having to explicitly investigate ecological indices or building ecological models. However, in order to understand detailed ecological consequences and to identify hydrological thresholds for sustaining the complete or parts of the wetland ecosystem, an in-depth study involving ecological indicators and species requirements is nevertheless needed.The RVA approach enables researchers to link and track the hydrologic and ecological responses to the desirable implementations or ecosystem research efforts. Since, the RVA targets were set as the median $315 \pm 25$ th percentile of the baseline data for each hydrologic indicator, the high variation of the streamflow data in Wadi systems 
https://doi.org/10.5194/hess-2020-599

might lead to a high range of RVA targets. Therefore, we recommend a combination of RVA approach and a statistical method such as ANOVA to test the level of alteration and their significance in different hydrologic indicators.

\section{Conclusions}

The spatio-temporal variation of groundwater sustainability and the streamflow alteration in the near and far climate changeimpacted future have been assessed under five different scenarios: (i) no groundwater withdrawal (ii) unaltered present-day groundwater withdrawal (iii) an increase in groundwater withdrawal (iv) minimum-, and (v) maximum water consumption. Our findings show that:

1) The significant reduction estimated for groundwater recharge under climate change coincides with rising demand from WUSs and water consumption.

325 2) The growing groundwater withdrawals in the future exacerbates the impact of climate change on the sustainable use of water resources in the Halilrood Basin.

3) A sustainable state is possible for the entire Halilrood Basin in near and far future if only consumptive water use is considered. However, several sub-basins would still be extremely unsustainable. Hence, water provisioning from sustainable to unsustainable sub-basins would be required.

330 4) The impacts of climate change and groundwater withdrawals on the freshwater ecosystems in the Jazmorian wetland Basin are expected to be intensified as a considerable alteration is estimated in the hydrologic regime of the Halilrood River (27 IHA indicators show significant changes in the far future and among these the RVA is classified as "high" and "moderate" for 18 IHA).

The combined results show that climate change has a stronger impact on hydrologic regime alterations and consequently on

335 the freshwater ecosystem in the near and far future as compared to groundwater withdrawals in Halilrood Basin. The presented results are useful for long-term planning which is required for a sustainable water resources management under changing future conditions.

\section{Author contribution}

NM, JK, and PDW developed the study design. NM performed the model simulations with essential support of JK who 340 carried out the EURO-CORDEX data processing. All authors substantially contributed to the interpretation of the results. NM wrote the initial draft of the manuscript and all co-authors discussed the results and revised the work carefully.

\section{Competing interests}

The authors declare that they have no conflict of interest. 
https://doi.org/10.5194/hess-2020-599

Hydrology and

Preprint. Discussion started: 13 January 2021

(c) Author(s) 2021. CC BY 4.0 License.

\section{Acknowledgements}

345 The German Academic Exchange Service (DAAD) and the Federal Ministry of Education and Research (BMBF) granted this research, through the special program 'Sustainable Water Management'(NaWaM/-ID: 57260501). JK acknowledges funding through the "GLANCE" project (Global change effects in river ecosystems; 01LN1320A) supported by BMBF.

\section{References}

Acero Triana, J.S., Chu, M.L., Guzman, J.A., Moriasi, D.N., and Steiner, J.L.: Evaluating the risks of groundwater extraction in an agricultural landscape under different climate projections. Water, 12, 1-20, https://doi.org/10.3390/w12020400, 2020.

Achite, M., and Ouillon, S.: Recent changes in climate, hydrology and sediment load in the Wadi Abd, Algeria (1970-2010). Hydrol. Earth Syst. Sc., 20, 1355-1372, https://doi.org/10.5194/hess-20-1355-2016, 2016.

Al Qatarneh, G.N., Al Smadi, B., Al-Zboon, K., and Shatanawi, K.M.: Impact of climate change on water resources in Jordan: a case study of Azraq basin. Appl. Water Sci., 8, 1-14, https://doi.org/10.1007/s13201-018-0687-9, 2018.

Arnold, J.G, Kiniry, J., Srinivasan, R., Williams, J., Haney, E., and Neitsch, S.: Soil and water assessment tool input/output documentation version 2012. Texas Water Resources Institute 7, 2012.

Arnold, J.G., Srinivasan, R., Muttiah, R.S., and Williams, J.R.: Large area hydrologic modeling and assessment part I: model development 1. J. Am. Water Resour. As., 34, 73-89, https://doi.org/10.1111/j.1752-1688.1998.tb05961.x, 1998.

Ashraf, S., AghaKouchak, A., Nazemi, A., Mirchi, A., Sadegh, M., Moftakhari, H.R., Hassanzadeh, E., Miao, C.Y., Madani,

K., Baygi, M.M. and Anjileli, H.: Compounding effects of human activities and climatic changes on surface water availability in Iran. Climatic change, 152, 379-91, https://doi.org/10.1007/s10584-018-2336-6, 2019.

Bao, A., Mu, G., Zhang, Y., Feng, X., Chang, C., and Yin, X.: Estimation of the rational water area for controlling wind erosion in the dried-up basin of the Ebinur Lake and its effect detection. Chinese Sci. Bull, 51, 68-74, https://doi.org/10.1007/s11434-006-8209-9, 2006.

365 Bierkens, M.F., and Wada, Y.: Non-renewable groundwater use and groundwater depletion: a review. Environ. Res. Lett., 14, 1-43, https://doi.org/10.1088/1748-9326/ab1a5f, 2019.

Boulton, A.J., and Hancock, P.J.: Rivers as groundwater-dependent ecosystems: a review of degrees of dependency, riverine processes and management implications. Aust. J. Bot., 54, 133-144, https://doi.org/10.1071/BT05074, 2006.

Caldwell, P.V., Sun, G., McNulty, S.G., Cohen, E.C., and Myers, J.M.: Impacts of impervious cover, water withdrawals, and 370 climate change on river flows in the conterminous US. Hydrol. Earth Syst. Sci., 16, 2839-2857, https://doi.org/10.5194/hess16-2839-2012, 2012.

Cuthbert, M.O., Taylor, R.G., Favreau, G., Todd, M.C., Shamsudduha, M., Villholth, K.G., MacDonald, A.M., Scanlon, B.R., Kotchoni, D.V., Vouillamoz, J.M., and Lawson, F.M.: Observed controls on resilience of groundwater to climate variability in sub-Saharan Africa. Nature, 572, 230-234, https://doi.org/10.1038/s41586-019-1441-7, 2019. 
https://doi.org/10.5194/hess-2020-599

Hydrology and

Preprint. Discussion started: 13 January 2021

(c) Author(s) 2021. CC BY 4.0 License.

Dash, C.J., Sarangi, A., Singh D., and Adhikary, P.: Numerical simulation to assess potential groundwater recharge and net groundwater use in a semi-arid region. Environ Monit Assess, 191, 1-14, https://doi.org/10.1007/s10661-019-7508-y, 2019.

Davijani, M.H., Banihabib, M., Anvar, A.N., and Hashemi, S.: Multi-objective optimization model for the allocation of water resources in arid regions based on the maximization of socioeconomic efficiency. Water Resour. Manag., 30, 927-946, https://doi.org/10.1007/s11269-015-1200-y, 2016.

de Graaf, I.E, Gleeson, T., van Beek, L.R., Sutanudjaja, E.H., and Bierkens, M.F.: Environmental flow limits to global groundwater pumping. Nature, 574, 90-94, https://doi.org/10.1038/s41586-019-1594-4, 2019.

Dienel, H-L., Shirazi, M.R., Schröder, S., and Schmithals, J.: Citizens' Participation in Urban Planning and Development in Iran: Routledge, New York, 1-340, 2017.

Eissa, M.A., Thomas, J.M., Pohll, G., Shouakar-Stash, O., Hershey, R.L., and Dawoud, M.: Groundwater recharge and

salinization in the arid coastal plain aquifer of the Wadi Watir delta, Sinai, Egypt. Appl. Geochem., 71, 48-62, https://doi.org/10.1016/j.apgeochem.2016.05.017, 2016.

Emam, A.R., Kappas, M., Akhavan, S., Hosseini, S.Z., and Abbaspour, K.C.: Estimation of groundwater recharge and its relation to land degradation: case study of a semi-arid river basin in Iran. Environ. Earth Sci., 74, 6791-803, https://doi.org/10.1007/s12665-015-4674-2, 2015.

390 Evans, J.P., Ji F., Abramowitz, G., and Ekström, M.: Optimally choosing small ensemble members to produce robust climate simulations. Environ. Res. Lett., 8, 1-4, http://dx.doi.org/10.1088/1748-9326/8/4/044050, 2013.

Giordano, M.: Global groundwater? Issues and solutions. Annu. Rev. Env. Resour., 34, 153-178, 2009.

Gleeson, T., and Wada, Y.: Assessing regional groundwater stress for nations using multiple data sources with the groundwater footprint. Environ. Res. Lett., 8, 1-9, http://dx.doi.org/10.1088/1748-9326/8/4/044010, 2013.

395 Haghighi, A.T., and Kløve, B.: Design of environmental flow regimes to maintain lakes and wetlands in regions with high seasonal irrigation demand. Ecol. Eng., 100, 120-129, https://doi.org/10.1016/j.ecoleng.2016.12.015, 2017.

Herrera-Pantoja, M., and Hiscock, K.: Projected impacts of climate change on water availability indicators in a semi-arid region of central Mexico. Environ. Sci. Policy, 54, 81-9, https://doi.org/10.1016/j.envsci.2015.06.020, 2015.

IPCC.: Climate Change 2013: The Physical Science Basis. Contribution of Working Group I to the Fifth Assessment Report

400 of the Intergovernmental Panel on Climate Change [Stocker, T.F., D. Qin, G.-K. Plattner, M, 2013.

Izady, A., Davary, K., Alizadeh, A., Ziaei, A.N., Akhavan, S., Alipoor, A., Joodavi, A., and Brusseau, M.L.: Groundwater conceptualization and modeling using distributed SWAT-based recharge for the semi-arid agricultural Neishaboor plain, Iran. Hydrogeol. J., 23, 47-68, http://dx.doi.org/10.1007/s10040-014-1219-9, 2015.

Jacob, D., Petersen, J., Eggert, B., Alias, A., Christensen, O.B., Bouwer, L.M., Braun, A., Colette, A., Déqué, M.,

405 Georgievski, G., and Georgopoulou, E.: EURO-CORDEX: new high-resolution climate change projections for European impact research. Reg. Environ. Change., 14, 563-78, https://doi.org/10.1007/s10113-013-0499-2, 2014. 
https://doi.org/10.5194/hess-2020-599

Hydrology and

Preprint. Discussion started: 13 January 2021

(c) Author(s) 2021. CC BY 4.0 License.

Kakaei, E., Moradi, H.R., Moghaddam, Nia, A.R., and Van Lanen, H.A.: Positive and negative human-modified droughts: a quantitative approach illustrated with two Iranian catchments. Hydrol. Earth Syst. Sc., 1-39, https://doi.org/10.5194/hess2018-124, 2018.

410 Kath, J., Boulton, A.J., Harrison, E.T., and Dyer, F.J.: A conceptual framework for ecological responses to groundwater regime alteration (FERGRA). Ecohydrology, 11, 1-17, https://doi.org/10.1002/eco.2010, 2018.

Khazaei, B., Khatami, S., Alemohammad, S.H., Rashidi, L., Wu, C., Madani, K., Kalantari, Z., Destouni, G., and Aghakouchak, A.: Climatic or regionally induced by humans? Tracing hydro-climatic and land-use changes to better understand the Lake Urmia tragedy. J. Hydrol., 569, 203-17, https://doi.org/10.1016/j.jhydrol.2018.12.004, 2019.

415 Lee, K.S., and Chung, E.S.: Hydrological effects of climate change, groundwater withdrawal, and land use in a small Korean watershed. Hydrol. Process., 21, 3046-56, https://doi.org/10.1002/hyp.6513, 2007.

Long, D., Chen, X., Scanlon, B.R., Wada, Y., Hong, Y., Singh, V.P., Chen, Y., Wang, C., Han, Z., and Yang, W.: Have GRACE satellites overestimated groundwater depletion in the Northwest India Aquifer? Sci. Rep., 6, 1-11, https://doi.org/10.1038/srep24398, 2016.

420 Mahmoodi, N., Kiesel, J., Wagner, D.P., and Fohrer, N.: Water use systems and soil and water conservation methods in a hydrological model of an Iranian Wadi system. J. Arid Land, 12, 545-560, https://doi.org/10.1007/s40333-020-0125-3, 2020a.

Mahmoodi, N., Wagner, D.P., Kiesel, J., and Fohrer, N.: modeling the impact of climate change on streamflow and major hydrological components of an Iranian Wadi system. Water Clim. Change, https://doi.org/10.2166/wcc.2020.098, $2020 \mathrm{~b}$.

425 Mahmoudpour, M., Khamehchiyan, M., Nikudel, M.R., and Ghassemi, M.R.: Numerical simulation and prediction of regional land subsidence caused by groundwater exploitation in the southwest plain of Tehran, Iran. Eng. Geol., 201, 6-28, https://doi.org/10.1016/j.enggeo.2015.12.004, 2016.

Messerschmid, C., Sauter, M., and Lange, J.: Field-based estimation and modelling of distributed groundwater recharge in a Mediterranean karst catchment, Wadi Natuf, West Bank. Hydrol. Earth Syst. Sci., 24. 887-917, https://doi.org/10.5194/hess-

$430 \quad$ 24-887-2020, 2020.

Modarres, R., and Sadeghi, S.: Spatial and temporal trends of dust storms across desert regions of Iran. Nat. Hazards, 90, 101-14, https://doi.org/10.1007/s11069-017-3035-8, 2018.

Moiwo, J.P., Lu W., Zhao, Y., Yang, Y., and Yang, Y.: Impact of land use on distributed hydrological processes in the semiarid wetland ecosystem of Western Jilin. Hydrol. Process., 24, 492-503, https://doi.org/10.1002/hyp.7503, 2010.

435 Nielsen, D.L., and Brock, M.A.: Modified water regime and salinity as a consequence of climate change: prospects for wetlands of Southern Australia. Climatic Change, 95, 523-33, https://doi.org/10.1007/s10584-009-9564-8, 2009.

Oki, T., and Kanae, S.: Global hydrological cycles and world water resources. Science, 313, 1068-72, https://doi.org/10.1126/science.1128845, 2006. 
https://doi.org/10.5194/hess-2020-599

Hydrology and

Preprint. Discussion started: 13 January 2021

(c) Author(s) 2021. CC BY 4.0 License.

Pahlevani Majdabady, M., Rasoulzadeh, A., Kanooni, A., and Ahmadzadeh, G.: Estimation of groundwater recharge originating from agricultural irrigation and rainfall in Shyramyn plain, Iran. Irrig. Drain., 69, 107-20, https://doi.org/10.1002/ird.2398, 2020.

Panahi, D.M., Kalantari, Z., Ghajarnia, N., Seifollahi-Aghmiuni, S., and Destouni, G.: Variability and change in the hydroclimate and water resources of iran over a recent 30-year period. Sci. Rep., 10, 1-9, https://doi.org/10.1038/s41598-02064089-y, 2020.

445 Perrone, D., and Jasechko, S.: Deeper well drilling an unsustainable stopgap to groundwater depletion. Nature Sustainability, 2, 773-82, https://doi.org/10.1038/s41893-019-0325-z, 2019.

Qaderi Nasab, F., and Rahnama, M.: Developing restoration strategies in Jazmurian wetland by remote sensing. Int. J. Environ. Sci. Te., 17, 2767-2782, https://doi.org/10.1007/s13762-019-02568-0, 2020.

Richey, A.S., Thomas, B.F., Lo, M.H., Reager, J.T., Famiglietti, J.S., Voss, K., Swenson, S., and Rodell, M.: Quantifying renewable groundwater stress with GRACE. Water Resour Res., 51, 5217-38, https://doi.org/10.1002/2015WR017349, 2015 .

Richter, B., Baumgartner, J., Wigington, R., and Braun, D.P.: How much water does a river need? Freshw. Biol., 37, 231249, https://doi.org/10.1046/j.1365-2427.1997.00153.x, 1997.

Richter, B.D, Baumgartner, J.V, Braun, D.P, and Powell, J.: A spatial assessment of hydrologic alteration within river 455 network. Regul. Rivers: Res. Manage., 14, 329-340, https://doi.org/10.1002/(SICI)10991646(199807/08)14:4\%3C329::AID-RRR505\%3E3.0.CO;2-E, 1998.

Richter, B.D., Baumgartner, J.V., Powell, J., and Braun, D.P.: A method for assessing hydrologic alteration within ecosystems. Conserv. Biol. 10, 1163-1174, https://doi.org/10.1046/j.1523-1739.1996.10041163.x, 1996.

SCI: Statistics Center of Iran, Index of publications. https://www.amar.org.ir/english, 2017.

460 Shahid, M., Cong, Z., and Zhang, D.: Understanding the impacts of climate change and human activities on streamflow: a case study of the Soan River basin, Pakistan. Theor. Appl. Climatol., 134, 205-219, https://doi.org/10.1007/s00704-0172269-4, 2018.

Sharifikia, M.: Environmental challenges and drought hazard assessment of Hamoun Desert Lake in Sistan region, Iran, based on the time series of satellite imagery. Nat. Hazards, 65, 201-17, https://doi.org/10.1007/s11069-012-0353-8, 2013.

465 Taylor, R.: Hydrology: when wells run dry. Nature, 516, 179-80, https://doi.org/10.1038/516179a, 2014.

Tebaldi, C., and Knutti, R.: The use of the multi-model ensemble in probabilistic climate projections. Phil TransR Soc A, 365, 2053-2075, https://doi.org/10.1098/rsta.2007.2076, 2007.

Thober, S., and Samaniego, L.: Robust ensemble selection by multivariate evaluation of extreme precipitation and temperature characteristics. J Geophys Res Atmos, 119, 594-613, https://doi.org/10.1002/2013JD020505, 2014.

470 Toews, M., and Allen, D.: Simulated response of groundwater to predicted recharge in a semi-arid region using a scenario of modelled climate change. Environ. Res. Lett., 4, 1-19, http://dx.doi.org/10.1088/1748-9326/4/3/035003, 2009. 
https://doi.org/10.5194/hess-2020-599

Preprint. Discussion started: 13 January 2021

(c) Author(s) 2021. CC BY 4.0 License.

Vu ,T.T., Kiesel, J., Guse, B., and Fohrer, F.: Analysis of the occurrence, robustness and characteristics of abrupt changes in streamflow time series under future climate change. Climate Risk Management, 26, 1-18, https://doi.org/10.1016/j.crm.2019.100198, 2019.

475 Wen, L., Macdonald, R., Morrison, T., Hameed, T., Saintilan, N., and Ling, J.: From hydrodynamic to hydrological modelling: Investigating long-term hydrological regimes of key wetlands in the Macquarie Marshes, a semi-arid lowland floodplain in Australia. J. hydro., 500, 45-61, https://doi.org/10.1016/j.jhydrol.2013.07.015, 2013.

Wu, G., Li, L., Ahmad, S., Chen, X., and Pan, X.: A dynamic model for vulnerability assessment of regional water resources in arid areas: a case study of Bayingolin, China. Water Resour. Manag., 27, 3085-3101, https://doi.org/10.1007/s11269-013480 0334-z, 2013.

Xue, L., Yang, F., Yang, C., Chen, X., Zhang, L., Chi, Y., and Yang, G.: Identification of potential impacts of climate change and anthropogenic activities on streamflow alterations in the Tarim River Basin, China. Sci. Rep., 7, 1-12, https://doi.org/10.1038/s41598-017-09215-z, 2017.

Yu, Y., Pi, Y., Yu, X., Ta, Z., Sun, L., Disse, M., Zeng, F., Li, Y., Chen, X., and Yu, R.: Climate change, water resources 485 and sustainable development in the arid and semi-arid lands of Central Asia in the past 30 years. J. Arid Land, 11, 1-14, https://doi.org/10.1007/s40333-018-0073-3, 2019.

Zhang, J., Zhang, X., and Xiao, H.: Study of the dynamic evaluation model of overall hydrological alteration degree based on the RVA and set pair analysis-Markov chain methods. Water Supp., 19, 1515-1524, https://doi.org/10.2166/ws.2019.020, 2019. 

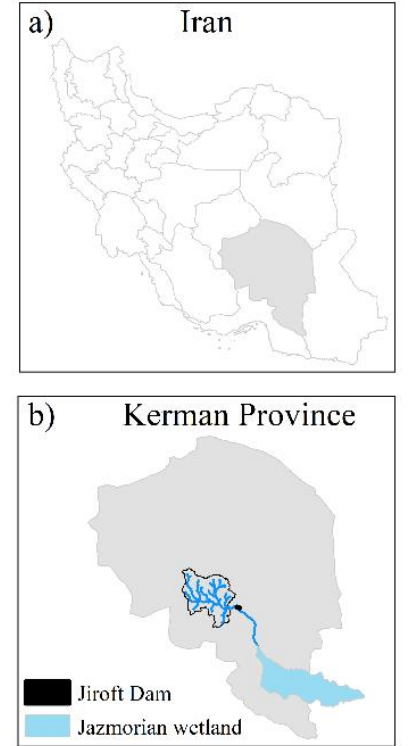

d)
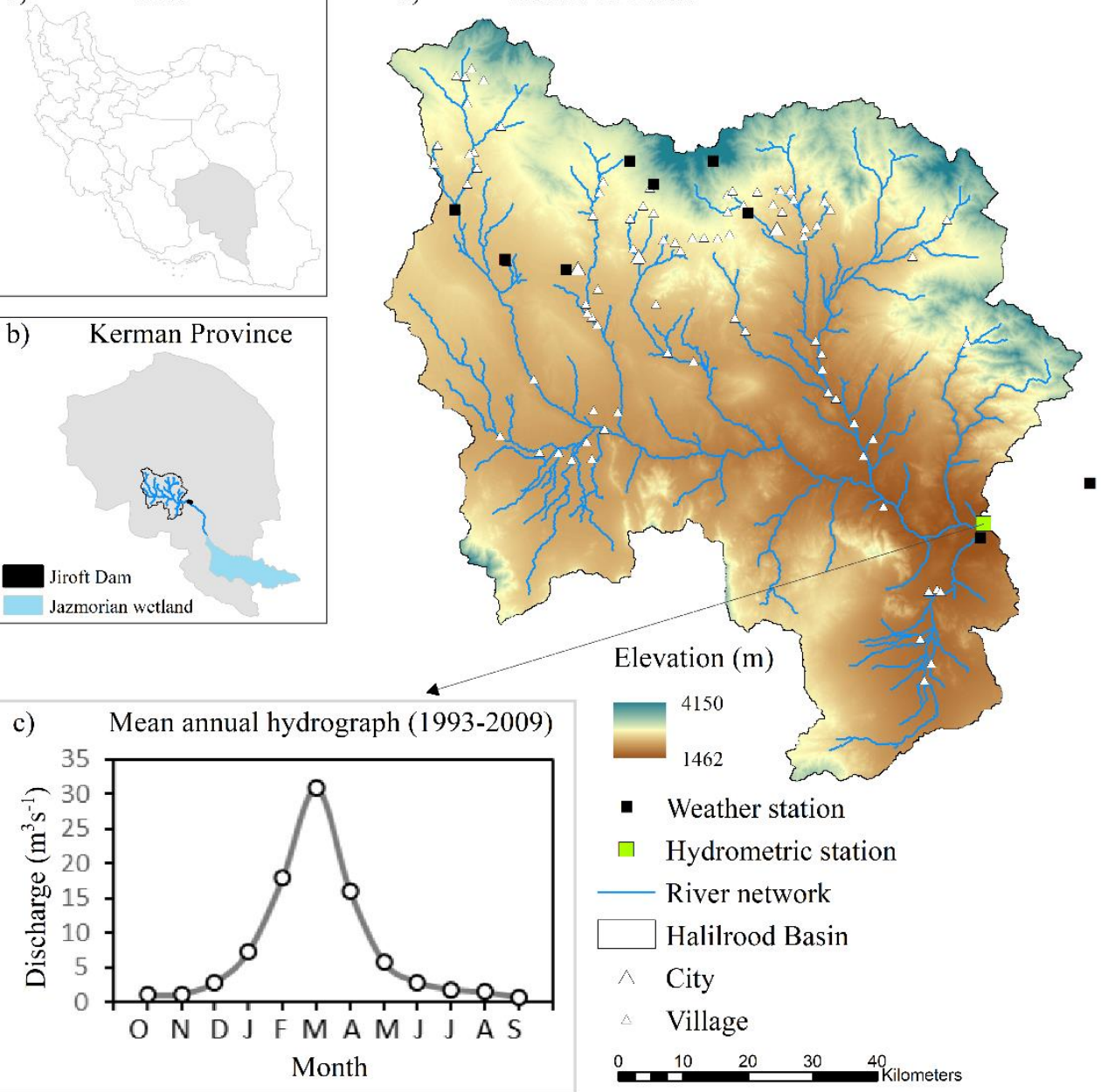

- Weather station

$\square \quad$ Hydrometric station

River network

Halilrood Basin

City

Village

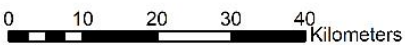

e)

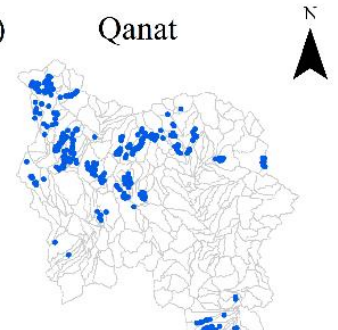

Well
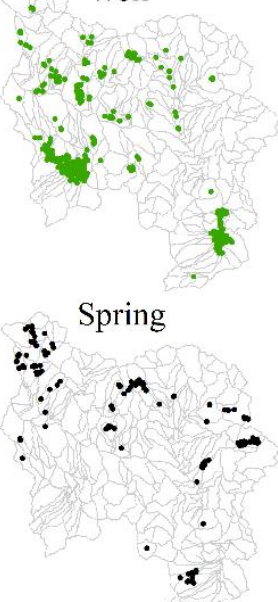

- Qanat

- Well

- Spring

Sub-basin

Sub-basin

Figure 1: Location of the Halilrood Basin, water use systems, and monitoring stations considered in this study. Average monthly flows derived from the observed data at the outlet of the basin. 
https://doi.org/10.5194/hess-2020-599

Preprint. Discussion started: 13 January 2021

(c) Author(s) 2021. CC BY 4.0 License.
Hydrology and Earth System Sciences Discussions
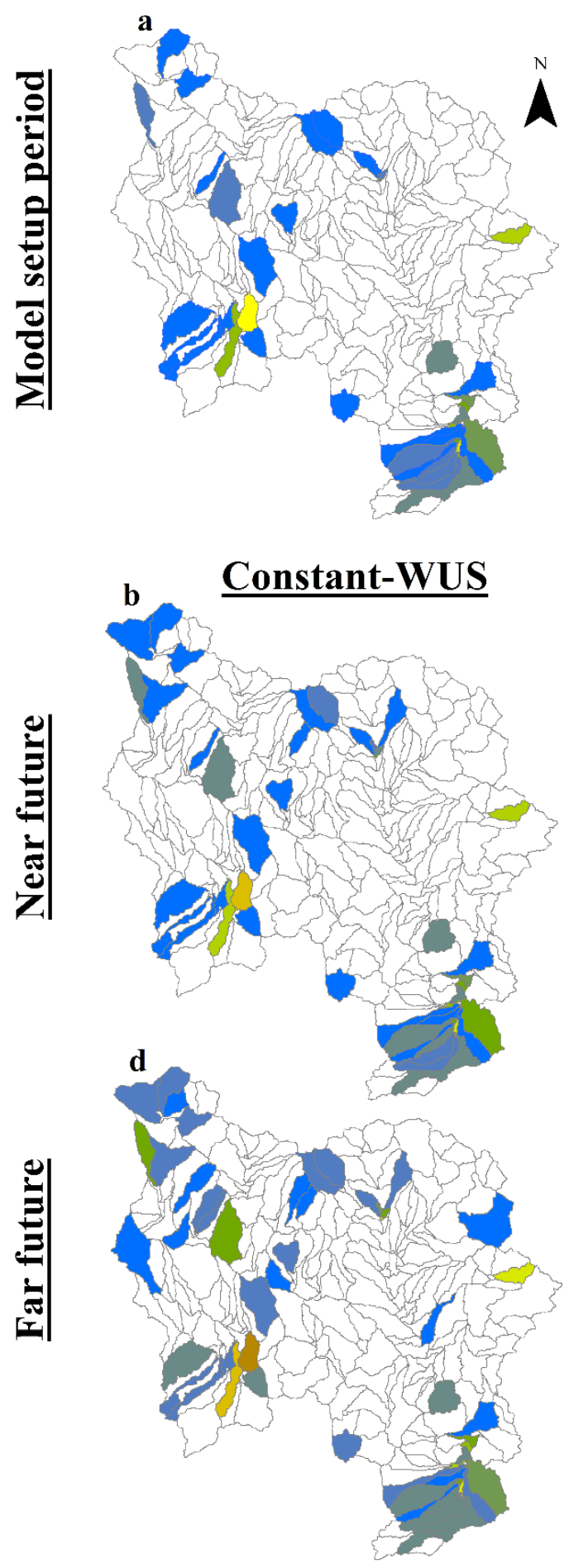

Groundwater withdrawal / Groundwater recharge

\begin{tabular}{|c|c|}
\hline $0.00-1.00$ & $10.01-15.00$ \\
\hline $1.01-2.00$ & $15.01-20.00$ \\
\hline $2.01-3.00$ & $20.01-25.00$ \\
\hline $3.01-4.00$ & $25.01-30.00$ \\
\hline $4.01-5.00$ & $30.01-35.00$ \\
\hline $5.01-6.00$ & $35.01-40.00$ \\
\hline $6.01-7.00$ & $40.01-50.00$ \\
\hline $7.01-8.00$ & $50.01-60.00$ \\
\hline $8.01-9.00$ & $60.01-70.00$ \\
\hline $9.01-10.00$ & $70.01-80.00$ \\
\hline
\end{tabular}

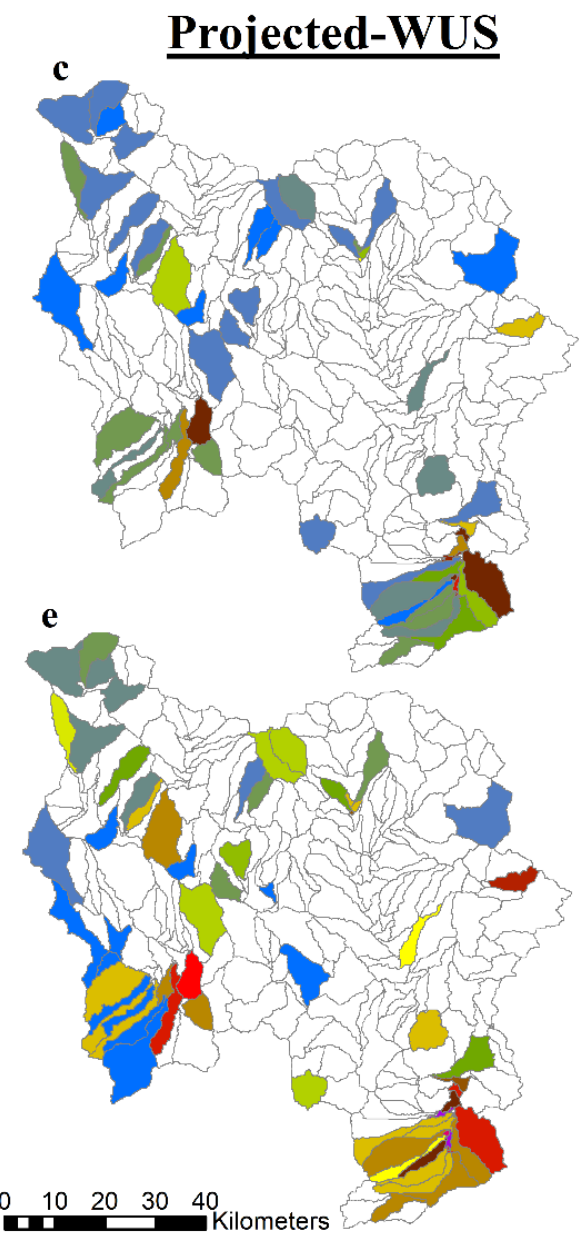


https://doi.org/10.5194/hess-2020-599

Preprint. Discussion started: 13 January 2021

(C) Author(s) 2021. CC BY 4.0 License.

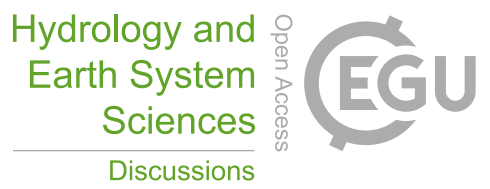

Figure 2: Unsustainable water use: The ratio of groundwater withdrawal to groundwater recharge for all sub-basins under two different scenarios: Constant-WUS: the number of water use systems in the basin remains unaltered in the future, and Projected-

WUS: the number of water use systems increases linearly with population growth. 
https://doi.org/10.5194/hess-2020-599

Preprint. Discussion started: 13 January 2021

(c) Author(s) 2021. CC BY 4.0 License.

(c) (1)



Figure 3: RVA (The Range of Variability Approach) deviation and classes of alteration (High (H), Moderate (M), and Low (L)) for each IHA (Indicators of Hydrologic Alterertion) indicator in the near and far future under three different scenarios: No-WUS: the water use systems are not considered, Constant-WUS: the number of water use systems in the basin remains unaltered in the future, and Projected-WUS: the number of water use systems increases linearly with population growth. 
https://doi.org/10.5194/hess-2020-599

Preprint. Discussion started: 13 January 2021

(c) Author(s) 2021. CC BY 4.0 License.

505 Table 1: Population of cities located in the Halilrood Basin according to the last census in 2017 and the future population projected based on the population growth rate suggested by presidency of I.R.I, Plan and Budget Organization (2019).

\begin{tabular}{lcccc}
\hline Cities & Population & Population & Mid. First Period 2045 & Mid. Second Period \\
& $\mathbf{2 0 1 1}$ & $\mathbf{2 0 1 7}$ & & $\mathbf{2 0 8 5}$ \\
\hline Bazanjan & 4325 & 4517 & 5592 & 7127 \\
Baft & 80528 & 84103 & 104119 & 132714 \\
Rabor & 33859 & 35362 & 43778 & 55801 \\
Total basin & 118712 & 123982 & 153489 & 195643 \\
\hline
\end{tabular}


https://doi.org/10.5194/hess-2020-599

Preprint. Discussion started: 13 January 2021

(c) Author(s) 2021. CC BY 4.0 License.

Table 2: Projected water demand from water use systems. Number of water use systems mentioned in parenthesis is estimated based on population growth in the future.

\begin{tabular}{|c|c|c|c|c|c|}
\hline WUS & $\begin{array}{l}\text { Mean discharge } \\
\left(\mathrm{m}^{3} \mathrm{~s}^{-1}\right)\end{array}$ & $\begin{array}{l}\text { Year } 2011 \\
\left(\text { mil.m }^{3} \mathrm{yr}^{-1}\right)\end{array}$ & $\begin{array}{l}\text { Year } 2017 \\
\left(\text { mil.m }^{3} \mathbf{y r}^{-1}\right)\end{array}$ & $\begin{array}{l}\text { Mid. of near future-2045 } \\
\left(\mathrm{mil}^{3} \mathrm{~m}^{3} \mathrm{yr}^{-1}\right)\end{array}$ & $\begin{array}{l}\text { Mid. of far future-2085 } \\
\left(\mathrm{mil}^{3} \mathrm{~m}^{3} \mathrm{yr}^{-1}\right)\end{array}$ \\
\hline Well & 0.01152 & (329) 119.52 & (344) 124.83 & (425) 154.54 & (542) 196.98 \\
\hline Qanat & 0.00211 & (262) 17.43 & (274) 18.21 & (338) 22.54 & (431) 28.73 \\
\hline Spring & 0.00134 & (170) 7.16 & (170) 7.16 & (170) 7.16 & (170) 7.16 \\
\hline WUS & 0.01497 & (761) 144.12 & (787) 150.20 & (934) 184.24 & 232.87 (1134) \\
\hline
\end{tabular}


https://doi.org/10.5194/hess-2020-599

Preprint. Discussion started: 13 January 2021

(c) Author(s) 2021. CC BY 4.0 License.

Table 3: Minimum and maximum estimated demand for consumptive water use according to the data reported for the water required and population growth currently and in the future.

\begin{tabular}{|c|c|c|c|c|}
\hline & $\begin{array}{l}\text { Year } 2011 \\
\left(\text { mil.m } \mathbf{m}^{3} \mathbf{y r}^{-1}\right)\end{array}$ & $\begin{array}{l}\text { Year } 2017 \\
\left(\text { mil.m }^{3} \mathbf{y r}^{-1}\right)\end{array}$ & $\begin{array}{l}\text { Mid. of near } \\
\text { future-2045 } \\
\left(\text { mil.m }^{3} \mathrm{yr}^{-1}\right)\end{array}$ & $\begin{array}{l}\text { Mid. of far future- } \\
2085 \\
\left(\mathrm{mil}^{\circ} \mathrm{m}^{3} \mathrm{yr}^{-1}\right)\end{array}$ \\
\hline $\begin{array}{l}\text { Min. water consumption: } 0.135 \mathrm{~m}^{3} \text { day }^{-1} \\
\text { person }^{-1}\end{array}$ & 5.84 & 6.11 & 7.56 & 9.64 \\
\hline $\begin{array}{l}\text { Max. water consumption: } 0.300 \mathrm{~m}^{3} \mathrm{day}^{-1} \\
\text { person }^{-1}\end{array}$ & 12.99 & 13.58 & 16.8 & 21.42 \\
\hline
\end{tabular}


https://doi.org/10.5194/hess-2020-599

Preprint. Discussion started: 13 January 2021

(c) Author(s) 2021. CC BY 4.0 License.

580 Table 4: Scenarios included in near and far future simulations to evaluate groundwater sustainability and hydrologic regime alteration on different spatial scales.

\begin{tabular}{lccccccc}
\hline Scenarios & Description & Climate & WUSs & Water & \multicolumn{2}{c}{ Groundwater } & Hydrologic \\
& change & including & consumption & sustainability & regime \\
& & water & only & Sub-basin & Entire & change \\
& & & & & scale & basin & \\
& & & & & & scale
\end{tabular}

\begin{tabular}{|c|c|c|}
\hline i. No WUS & Water & \\
\hline & systems do not & $*$ \\
\hline
\end{tabular}

ii. Constant- Currently

WUS existing water

use systems in

the basin

remain

unaltered

iii. Projected- The number of

WUS water use

systems

increase

linearly with

population

growth

iv. Min- Minimum

Consumption amount of water 
https://doi.org/10.5194/hess-2020-599

Hydrology and

Preprint. Discussion started: 13 January 2021

(c) Author(s) 2021. CC BY 4.0 License.

\author{
required per \\ person per day \\ in Iran
}

v. Max- Maximum

Consumption amount of water

required per *

person per day

in Iran

585

590

595

600 
https://doi.org/10.5194/hess-2020-599

Preprint. Discussion started: 13 January 2021

(c) Author(s) 2021. CC BY 4.0 License.

Table 5: The used set of 32 indicators of hydrologic alteration categorized into five groups (Richter et al., 1997).

\begin{tabular}{|c|c|c|}
\hline IHA parameters group & Hydrologic parameters & Unit \\
\hline $\begin{array}{l}\text { Group 1. Magnitude of monthly } \\
\text { water conditions }\end{array}$ & Median flow for each calendar month & $\begin{array}{l}\mathrm{m}^{3} \mathrm{~s}^{-1} \\
\mathrm{~m}^{3} \mathrm{~s}^{-1}\end{array}$ \\
\hline $\begin{array}{l}\text { Group 2. Magnitude of annual } \\
\text { extreme discharge events with } \\
\text { different durations }\end{array}$ & $\begin{array}{l}\text { 1-day minimum flow (1-day min) } \\
\text { 3-day minimum flow (3-day min) } \\
\text { 7-day minimum flow (7-day min) } \\
\text { 30-day minimum flow (30-day min) } \\
\text { 90-day minimum flow (90-day min) } \\
\text { 1-day maximum flow (1-day max) } \\
\text { 3-day maximum flow (3-day max) } \\
\text { 7-day maximum flow (7-day max) } \\
\text { 30-day maximum flow (30-day max) } \\
\text { 90-day maximum flow (90-day max) } \\
\text { Base flow index (Base flow) }\end{array}$ & $\begin{array}{l}\mathrm{m}^{3} \mathrm{~s}^{-1} \\
\mathrm{~m}^{3} \mathrm{~s}^{-1} \\
\mathrm{~m}^{3} \mathrm{~s}^{-1} \\
\mathrm{~m}^{3} \mathrm{~s}^{-1} \\
\mathrm{~m}^{3} \mathrm{~s}^{-1} \\
\mathrm{~m}^{3} \mathrm{~s}^{-1} \\
\mathrm{~m}^{3} \mathrm{~s}^{-1} \\
\mathrm{~m}^{3} \mathrm{~s}^{-1} \\
\mathrm{~m}^{3} \mathrm{~s}^{-1} \\
\mathrm{~m}^{3} \mathrm{~s}^{-1} \\
\mathrm{~m}^{3} \mathrm{~s}^{-1}\end{array}$ \\
\hline $\begin{array}{l}\text { Group 3.Timing of annual extreme } \\
\text { water conditions }\end{array}$ & $\begin{array}{l}\text { Date of annual minimum flow (Date min) } \\
\text { Date of annual maximum flow (Date max) }\end{array}$ & $\begin{array}{l}\text { day of year } \\
\text { day of year }\end{array}$ \\
\hline $\begin{array}{l}\text { Group 4. Frequency and duration of } \\
\text { high and low pulses }\end{array}$ & $\begin{array}{l}\text { Number of low pulses each year (Lo pulse) } \\
\text { Number of high pulses each year (Hi pulse) } \\
\text { Duration of low pulses (Lo pulse D) } \\
\text { Duration of high pulses (Hi pulse D) } \\
\text { Number of zero flow days (Zero days) }\end{array}$ & $\begin{array}{c}\text { dimensionless } \\
\text { dimensionless } \\
\text { dimensionless } \\
\text { dimensionless } \\
\text { days }\end{array}$ \\
\hline $\begin{array}{l}\text { Group 5. Rate and frequency of } \\
\text { water condition changes }\end{array}$ & $\begin{array}{l}\text { Median rate of positive changes in flow (Rise rate) } \\
\text { Median rate of negative changes in flow (Fall rate) }\end{array}$ & $\begin{array}{l}\mathrm{m}^{3} \mathrm{~s}^{-1} \text { day }^{-1} \\
\mathrm{~m}^{3} \mathrm{~s}^{-1} \text { day }^{-1}\end{array}$ \\
\hline
\end{tabular}


https://doi.org/10.5194/hess-2020-599

Preprint. Discussion started: 13 January 2021

(c) Author(s) 2021. CC BY 4.0 License.

(c) (i)

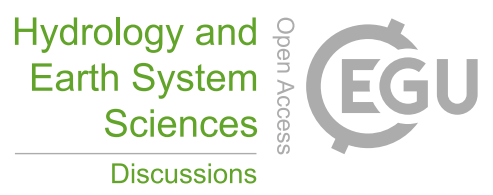

615

Table 6: Average annual groundwater recharge simulated on the entire basin scale in different periods.

\begin{tabular}{llll} 
Model setup period & Near future climate & Far future climate \\
$(\mathbf{1 9 7 9 - 2 0 0 9 )}$ & & scenario (2030-2059) & scenario (2070-2099) \\
\hline 385 & & 172 \\
\hline
\end{tabular}

620

625 
https://doi.org/10.5194/hess-2020-599

Preprint. Discussion started: 13 January 2021

(C) Author(s) 2021. CC BY 4.0 License.

635 Table 7: Groundwater sustainability on the entire basin scale under three scenarios: Projected-WUS: the number of water use systems increase linearly with population growth, Min- and Max Consumption: the minimum and maximum water demand corresponded to population growth in the future.

Groundwater sustainability scenarios

Model setup period (1979-2009) Near future (2030-2059) Far future (2070-2099)

Projected-WUS

Min-Consumption

Max-Consumption
0.4

0.015

0.034
0.59

0.024

0.054

1.35

0.056

0.124

640

645

650 
Table 8: Absolute change for each Indicators of Hydrologic Alteration (IHA) (significant changes highlighted in bold digits) in the future under three different scenarios: No-WUS: the water use systems are not considered, Constant-WUS: the number of water use systems in the basin remains unaltered in the future, and Projected-WUS: the number of water use systems increases linearly with population growth. Percentage of RVA (The Range of Variability Approach) deviation is shown in brackets.

\begin{tabular}{|c|c|c|c|c|c|c|c|}
\hline \multirow{2}{*}{ 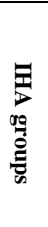 } & \multirow{2}{*}{ IHA } & \multicolumn{3}{|c|}{ Near future } & \multicolumn{3}{|c|}{ Far future } \\
\hline & & NO-WUS & $\begin{array}{l}\text { Constant- } \\
\text { WUS }\end{array}$ & $\begin{array}{l}\text { Projected- } \\
\text { WUS }\end{array}$ & NO-WUS & $\begin{array}{l}\text { Constant- } \\
\text { WUS }\end{array}$ & $\begin{array}{l}\text { Projected- } \\
\text { WUS }\end{array}$ \\
\hline \multirow{12}{*}{ 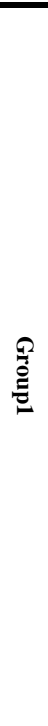 } & January & $-6.3(-13)$ & $-7.0(-47)$ & $-7.8(-68)$ & $-8.8(-20)$ & $-9.4(-33)$ & $-9.9(-27)$ \\
\hline & February & $-2.8(-13)$ & $-4.2(-27)$ & $-5.8(-33)$ & $-9.6(+7)$ & $-10.7(+7)$ & $-11.9(+13)$ \\
\hline & March & $-10.1(0)$ & $-11.6(+6)$ & $-13.2(-7)$ & $-18.2(0)$ & $-19.2(-13)$ & $-20.2(-33)$ \\
\hline & April & $-5.5(-13)$ & $-6.4(-27)$ & $-7.4(-13)$ & $-10.1(-40)$ & $-10.6(-27)$ & $-11.1(-40)$ \\
\hline & May & $-2.5(-20)$ & $-3.2(-20)$ & $-3.8(-13)$ & $-5.3(-27)$ & $-5.6(-27)$ & $-5.9(-20)$ \\
\hline & June & $-1.4(-47)$ & $-1.8(-40)$ & $-2.2(-33)$ & $-3.3(-40)$ & $-3.5(-40)$ & $-3.7(-33)$ \\
\hline & July & $-1.1(-47)$ & $-1.4(-33)$ & $-1.7(-40)$ & $-2.4(-68)$ & $-2.5(-60)$ & $-2.6(-60)$ \\
\hline & August & $-1.1(-53)$ & $-1.2(-53)$ & $-1.4(-47)$ & $-1.9(-73)$ & $-2.0(-73)$ & $-2.0(-73)$ \\
\hline & September & $-0.7(-60)$ & $-0.8(-60)$ & $-1.0(-60)$ & $-1.3(-73)$ & $-1.4(-73)$ & $-1.4(-73)$ \\
\hline & October & $-0.7(-60)$ & $-0.8(-47)$ & $-0.9(-53)$ & $-1.2(-73)$ & $-1.3(-68)$ & $-1.3(-68)$ \\
\hline & November & $-0.5(-53)$ & $-0.6(-53)$ & $-0.7(-40)$ & $-0.8(-47)$ & $-0.9(-27)$ & $-0.9(-27)$ \\
\hline & December & $-2.7(+7)$ & $-3.0(-7)$ & $-3.3(-7)$ & $-3.8(-20)$ & $-3.9(-20)$ & $-4.1(-20)$ \\
\hline \multirow{10}{*}{ 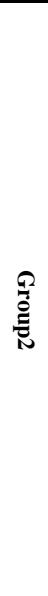 } & 1-day min & $-0.2(-100)$ & $-0.2(-87)$ & $-0.2(-87)$ & $-0.3(-100)$ & $-0.3(-100)$ & $-0.3(-100)$ \\
\hline & 3-day min & $-0.2(-93)$ & $-0.3(-87)$ & $-0.3(-80)$ & $-0.4(-87)$ & $-0.4(-87)$ & $-0.4(-87)$ \\
\hline & 7-day $\min$ & $-0.3(-60)$ & $-0.3(-53)$ & $-0.4(-60)$ & $-0.4(-80)$ & $-0.4(-80)$ & $-0.4(+80)$ \\
\hline & 30-day min & $-0.2(-53)$ & $-0.3(-47)$ & $-0.4(-47)$ & $-0.6(-73)$ & $-0.6(-68)$ & $-0.7(-68)$ \\
\hline & 90-day min & $-0.6(-53)$ & $-0.7(-53)$ & $-0.8(-47)$ & $-1.1(-68)$ & $-1.1(-68)$ & $-1.1(-73)$ \\
\hline & 1-day max & $-110.1(-13)$ & $-122.8(-7)$ & $-135.5(0)$ & $-199.1(-7)$ & $-206.7(-7)$ & $-214.3(-20)$ \\
\hline & 3-day max & $-62.5(-20)$ & $-71.1(-13)$ & $-79.7(-13)$ & $-115.2(-13)$ & $-120.9(-13)$ & $-126.6(-20)$ \\
\hline & 7-day max & $-40.8(-40)$ & $-46.5(-33)$ & $-52.1(-33)$ & $-72.3(-27)$ & $-76.3(-40)$ & $-80.3(-47)$ \\
\hline & 30-day max & $-22.7(-33)$ & $-25.6(-27)$ & $-28.4(-20)$ & $-36.3(-27)$ & $-38.4(-27)$ & $-40.5(-33)$ \\
\hline & 90-day max & $-10.6(-20)$ & $-12.5(-27)$ & $-14.4(-33)$ & $-19.7(-27)$ & $-21.0(-27)$ & $-22.4(-40)$ \\
\hline
\end{tabular}




\begin{tabular}{|c|c|c|c|c|c|c|c|}
\hline & Base flow & $-0.01(-60)$ & $-0.01(-53)$ & $-0.02(-60)$ & $-0.02(-80)$ & $-0.02(-80)$ & $-0.02(-80)$ \\
\hline \multirow{2}{*}{ 足 } & Date min & $-85(+27)$ & $-84.0(+20)$ & $-85(+27)$ & $-137(+20)$ & $-136.0(+20)$ & $-137(+20)$ \\
\hline & Date max & $-53(-7)$ & $-52.0(0)$ & $-53(0)$ & $-61(0)$ & $-60.0(0)$ & $-61(0)$ \\
\hline \multirow{5}{*}{ 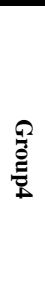 } & Lo pulse & $2.6(+47)$ & $2.6(+47)$ & $2.6(+53)$ & $2.4(+73)$ & $2.4(+73)$ & $2.1(+80)$ \\
\hline & Lo pulse D & $2.4(-27)$ & $2.3(-27)$ & $2.3(-27)$ & $2.0(-53)$ & $2.1(-53)$ & $2.4(-68)$ \\
\hline & Hi pulse & $-2.0(-33)$ & $-2.0(-33)$ & $-2.0(-40)$ & $-1.6(-7)$ & $-1.6(-7)$ & $-1.8(-13)$ \\
\hline & Hi pulse D & $-1.9(-13)$ & $-1.9(-13)$ & $-2.3(-47)$ & $-1.3(-27)$ & $-1.3(-27)$ & $-1.6(-47)$ \\
\hline & Zero days & 78(-27) & 79(-27) & $83(-27)$ & $130(-47)$ & $132(-40)$ & $136(-47)$ \\
\hline \multirow{2}{*}{ 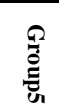 } & Rise rate & $0.16(0)$ & $0.003(-33)$ & $-0.08(-40)$ & $0.89(-13)$ & $0.6(-27)$ & $0.53(-47)$ \\
\hline & Fall rate & $-0.16(-13)$ & $-0.01(+7)$ & $0.1(-7)$ & $-0.45(-13)$ & $-0.25(-13)$ & $-0.08(-7)$ \\
\hline
\end{tabular}

